\title{
PENERAPAN MODEL PEMBELAJARAN KUANTUM PADA MATAKULIAH FISIKA KUANTUM DITINJAU DARI MOTIVASI BERPRESTASI
}

\author{
Aris Doyan \\ Program Studi Pendidikan Fisika \\ Universitas Mataram \\ Mataram, Indonesia \\ Email : $\underline{\text { arisdoyan@unram.ac.id }}$
}

\begin{abstract}
This study aims to determine (1) the influence of quantum and conventional learning model on the learning achievement of quantum physics course, (2) the influence of student achievement motivation on learning achievement of quantum physics course, and (3) the interaction between the quantum and conventional learning model with achievement motivation students' learning achievement of quantum physics course. This type of research is quasi experiment with forms of research design is a $2 \times 2$ factorial design. The population in this study were all students of physical education in the school year 2011/2012 VI semester FKIP Mataram University with a sampling technique that random sampling. There are two samples of the study as control and experimental class. The control class given conventional learning while the experimental class was given treatment with quantum learning model. Data were analyzed using analysis of variance (ANOVA) of two different cell. Where, (1) there is the influence of quantum and conventional learning model on the learning achievement of quantum physics course that is obtained significance level $(0.047)<(0.05)$, (2) there is influence student achievement motivation high and low categories of the learning achievement of courses quantum physics is obtained significance level $(0.000)<(0.05)$, and (3) there is no interaction between the quantum and conventional learning model with student achievement motivation on learning achievement of quantum physics course that is obtained significance level $(0.190)>(0,05)$.
\end{abstract}

Keywords: Quantum Learning, Achievement Motivation, Achievement Quantum Physics.

\section{Pendahuluan}

Program studi pendidikan fisika sejak diresmikan juli 1997 sampai saat ini telah terakreditasi B oleh BAN PT telah mengalami banyak perubahan dari segala sektor terutama pada perubahan kurikulum. Sesuai dengan fungsinya kurikulum dapat mengantarkan peserta didik mampu menyesuaikan diri dengan kehidupan masyarakat, mengembangkan kognitif, afektif, psikomotor, memberikan pengalaman belajar untuk melanjutkan pendidikan dari level teknisi untuk menuju level ahli [1]. Fungsi kurikulum ini belum dapat terlaksana sepenuhnya di program studi pendidikan fisika terutama pada ranah pengembangan kognitif yang diberikan pada setiap perkuliahan.

Pada perkuliahan fisika kuantum banyak ditemui kesulitan dalam memahami materi, karena materinya oleh mahasiswa dianggap sulit dan susah untuk dimengerti. Hal ini terlihat dari nilai rata-rata hasil belajar fisika kuantum untuk tiga tahun perkuliahan terakhir, seperti terlihat pada tabel 1 berikut.

Tabel 1. Nilai Rata-rata Perkuliahan Fisika Kuantum

\begin{tabular}{lll}
\hline No & Tahun Pelajaran & Rerata \\
\hline 1. & $2007 / 2008$ & 62.45 \\
2. & $2009 / 2010$ & 65,67 \\
3. & $2010 / 2011$ & 63.81 \\
\hline \multicolumn{3}{l}{ Nilai rata-rata perkuliahan fisika kuntum dari tiga }
\end{tabular}
tahun terakhir ini cendrung rendah, ada beberapa hal yang penyebabnya yaitu mahasiswa kurang tekun mengerjakan tugas yang diberikan, kurang ulet menghadapi kesulitan, cepat bosan dalam belajar yang ditandai dengan rendahnya motivasi dalam belajar [2] Penyebab lain dari hasil observasi awal yang peneliti lakukan peserta didik( mahasiswa) menginginkan adanya perubahan dalam model pembelajaran yang diberikan. Dari latar belakang masalah tersebut penulis melakukan penelitian menerapkan model pembelajaran kuantum pada matakuliah fisika kuantum ditinjau dari motivasi berprestasi mahasiswa program studi pendidikan fisika FKIP Unversitas Mataram.

Tujuan dari penelitian ini adalah untuk mengetahui:

a. Pengaruh Perbedaan hasil belajar antara mahasiswa yang menggunakan model pembelajaran kuantum dengan yang menggunakan pembelajaran konvensional.

b. Pengaruh Perbedaan hasil belajar antara mahasiswa yang memiliki motivasi berprestasi tinggi dan yang memiliki motivasi berprestasi rendah.

c. Pengaruh Interaksi antara model pembelajaran dengan motivasi berprestasi terhadap hasil belajar. 


\section{TINJAUAN PUSTAKA}

\section{A. Model Pembelajaran Kuantum}

Pembelajaran kuantum mencakup petunjuk spesifik untuk menciptakan lingkungan belajar yang efektif, merancang kurikulum, menyampaikan isi, dan memudahkan proses belajar. Penggunaan model pembelajaran kuantum adalah pengubahan bermacam-macam interaksi yang ada didalam dan disekitar momen belajar dengan menyingkirkan hambatan yang menghalangi proses belajar alamiah, menyusun bahan pengajaran yang sesuai, cara efektif pembelajaran, dan keterlibatan aktif siswa dan guru [3].

Pembelajaran kuantum juga mengandung arti Quick (cepat) dan Quality (berkualitas). Bahwasannya proses pembelajaran itu berlangsung cepat sesuai dengan alokasi waktu yang ditetapkan, namun tetap mencapai sasaran dan tujuannya. Dengan kata lain, kualitas hasil pembelajaran dapat dipertanggungjawabkan [4].

Pembelajaran kuantum sebagai interaksi yang mengubah energi menjadi cahaya. Semua kehidupan adalah energi. Persamaan yang terkenal dalam fisika kuantum adalah massa kali kecepatan cahaya kuadrat sama dengan energi. Tubuh kita secara fisik adalah materi, sebagai peserta didik adalah meraih energi sebaik mungkin cahaya; interaksi, hubungan, inspirasi agar menghasilkan energi cahaya [5].

Pembelajaran kuantum adalah salah satu model pembelajaran yang menggabungkan antara sugesti, cara-cara belajar cepat dan neorolinguistik program dengan menggunakan kerangka perancangan Quantum Teaching yaitu TANDUR (Tumbuhkan, Alami, Namai, Demonstrasikan, Ulangi dan Rayakan).

Adapun maksudnya adalah: menumbuhkan minat dengan memuaskan "apakah manfaatnya bagiku (pelajar)" dan memanfaatkan kehidupan pelajar; menciptakan atau mendatangkan pengalaman umum yang dapat dimengerti oleh semua pelajar; menamai kegiatan yang akan dilakukan selama proses belajar mengajar dengan menyediakan kata kunci, model, rumus, strategi, sebuah "masukan"; menyediakan kesempatan bagi pelajar untuk mendemonstrasikan bahwa mereka tahu; menunjuk beberapa pelajar untuk mengulangi materi dan menegaskan "aku tahu bahwa aku memang tahu ini"; merayakan atas keberhasilan yang sudah dilakukan oleh pelajar sebagai pengakuan untuk penyelesaian, partisipasi, dan memperoleh keterampilan dan ilmu pengetahuan [5].

\section{Motivasi Berprestasi}

Motivasi berprestasi individu merupakan tendensi untuk meraih sukses dan menghindari kegagalan [6]. Selanjutnya usaha yang dilakukan individu untuk mengatasi kesulitan untuk mencapai prestasi diri atau dorongan seseorang untuk mencapai keberhasilan disimpulkan sebagai motivasi berprestasi [7]. Seseorang yang memiliki motivasi berprestasi mempunyai ciri berupa; tidak mudah menyerah dalam mencapai sukses, menampilkan hasil yang terbaik pada tugas yang diberikan, menyukai situasi yang menantang, dalam melakukan sesuatu tidak berharap hadiah, dalam belajar seakan-akan dikejar waktu, mencari cara-cara yang unik dalam menyelesaikan masalah dan mempunyai sikap kreatif [8].

\section{Metode Penelitian}

Populasi dan sampel (total sampling) dalam penelitian ini adalah seluruh mahasiswa semester VI program studi pendidikan fisika tahun pelajaran 2011/2012. Pengumpulan data tentang motivasi berprestasi mahasiswa berupa angket yang diberikan sebelum pembelajaran menggunakan skala Likert [9]. Hasil skor angket motivasi berprestasi ditentukan berdasarkan pedoman konversi skor yaitu motivasi berprestasi tinggi jika skornya lebih besar sama dengan rata-rata gabungannya dan motivasi berprestasi rendah jika skornya lebih kecil rata-rata gabungannya.

Pengumpulan data tentang prestasi belajar matakuliah fisika kuantum yang terdiri dari lima pokok bahasan yaitu ; teori yang mendasari lahirnya fisika kuantum, konsep-konsep dasar fisika kuantum, operator dalam fisika kuantum, persamaan gerak dalam fisika kuantum, potensial sederhana yang masing-masing pokok bahasan dilakukan tes awal selanjutnya dilaksanakan tes akhir baik pada kelompok kontrol maupun kelompok eksperimen [10]. Tes hasil belajar disusun tes dalam bentuk esai. Hasil pengukuran yang berupa jumlah skor dari jumlah jawaban benar menggambarkan prestasi belajar mata kuliah fisika kuantum.

Peningkatan hasil belajar mata kuliah fisika kuantum siswa diperoleh dengan menghitung besarnya skor gain yang dinormalisasi (N-gain). Besarnya N-gain dihitung dengan rumus [11].

$$
N-\text { gain }=\frac{S_{\text {post }}-S_{\text {pres }}}{S_{\text {mahs }}-S_{\text {pres }}} \times 100 \%
$$

Nilai N-gain dikelompokkan dalam kategori tinggi, sedang, dan rendah yang dicantumkan dalam Tabel 2.

Tabel 2. Kriteria Skor N-gain

\begin{tabular}{cc}
\hline Nilai N-gain & Kategori \\
\hline $70<\mathrm{N}$-gain & Tinggi \\
$30 \leq \mathrm{N}$-gain $\leq 70$ & Sedang \\
N-gain $<30 \%$ & Rendah
\end{tabular}

Sebelum data dianalisis, terlebih dahulu dilakukan uji persyaratan analisis. Uji persyarat 
analisis meliputi uji normalitas dan uji homogenitas data, menggunakan Program SPSS 20. Uji normalitas membagi rasio skewness dengan standard error skewness dan membagi rasio kurtosis dengan standard error kurtosis, sehingga dari hasil pembagian diperoleh nilai skewness dan kurtosis berada pada kisaran nilai -2 sampai +2 maka dapat dikatakan distribusi nilai adalah normal. Selanjutnya untuk uji homogenitas nilai signifikansi harus lebih besar dari 0,05 , sehingga demikian dapat dikatakan variansi pada data adalah homogen.

Analisis data uji hipotesis dalam penelitian ini digunakan analisis variansi dua jalur (Anava Dua Jalur) dan uji Mann-Whitney untuk data yang tidak normal dengan taraf signifikansi 0.05 .

\section{HaSil dan PEMBahasan}

Sebelum dilakukan uji hipotesis, terlebih dahulu disajikan data motivasi berprestasi dan skor rata-rata hasil belajar fisika siswa pada kelas kontrol dan kelas eksperimen. Data motivasi berprestasi dan prestasi belajar disajikan pada Tabel 3 dan Tabel 4.

Tabel 3. Data Motivasi Berprestasi Mahasiswa

\begin{tabular}{lllllll}
\hline Kelas & N1 & N2 & N3 & N4 & N5 & N6 \\
\hline Kontrol & 19 & 81 & 59 & 71 & 9 & 10 \\
Eksperimen & 25 & 130 & 86 & 72 & 13 & 12 \\
Rata-rata Motivasi berprestasi & & & 71,49 \\
\hline Keterangan : & & & & \\
N1 = Jumlah Data & & & & \\
N2 = Nilai Tertinggi & & & & \\
N3 = Nilai Terendah & & & \\
N4 = Rata-rata \\
N5 = Jumlah Mahasiswa Motivasi Berprestasi Tinggi \\
N6 = Jumlah Mahasiswa Motivasi Berprestasi \\
\\
Rendah
\end{tabular}

Tabel 4. Data Kemampuan Awal dan Akhir Kelas Kontrol dan Eksperimen Mahasiswa Semester VI Program Studi Pendidikan Fisika Tahun Pelajaran 2011/2012.

\begin{tabular}{lllllllll}
\hline \multirow{2}{*}{ Keterangan } & \multirow{2}{*}{ Kemampuan } & $\begin{array}{l}\text { Jumlah } \\
\text { Sampel }\end{array}$ & $\begin{array}{l}\text { Nilai } \\
\text { Tertinggi }\end{array}$ & $\begin{array}{l}\text { Nilai } \\
\text { Terendah }\end{array}$ & $\begin{array}{l}\text { Rata } \\
\text {-rata }\end{array}$ & $\begin{array}{l}\text { Standar } \\
\text { Deviasi }\end{array}$ & N-gain & Kategori \\
\hline \multirow{2}{*}{ Kelas Kontrol } & Awal & 19 & 60 & 40 & 49,00 & 7,00 & 47,46 & \multirow{2}{*}{ Sedang } \\
& Akhir & 19 & 90 & 55 & 73,32 & 11,86 & & \\
\multirow{2}{*}{ Kelas } & Awal & 25 & 60 & 40 & 53,00 & 6,00 & 58,22 & \multirow{2}{*}{ Sedang } \\
\hline
\end{tabular}

Pada Tabel 3 terlihat motivasi berprestasi untuk kelas eksperimen lebih tinggi dari kelas kontrol baik untuk kelompok motivasi berprestasi tinggi maupun kelompok motivasi berprestasi rendah ini menujukkan motivasi berprestasi mahasiswa kelas eksperimen tidak mudah menyerah dalam mencapai sukses dalam belajar fisika kuantum, menampilkan hasil yang terbaik pada tugas yang diberikan dan dapat menyelesaikan soal-soal yang menantang sesuai dengan ciri-ciri motivasi berprestasi [8].

Data pada Tabel 4 terlihat bahwa terdapat perbedaan peningkatan prestasi belajar yang signifikan antara kedua kelas, dimana pencapaian prestasi belajar pada kelas eksperimen yang menggunakan pembelajaran kuantum lebih baik dibanding kelas kontrol. Perbandingan tes awal, tes akhir, dan N-gain antara kedua kelas ditampilkan pada Gambar 1. Selanjutnya data peningkatan (Ngain) prestasi belajar materi fisika kuantum untuk lima pokok bahasan terlihat pada Tabel 5 .
Pada Tabel 5 dapat disimpulkan bahwa terdapat perbedaan peningkatan pemahaman konsep yang signifikan antara kedua kelas untuk setiap materi, dimana pencapaian pemahaman konsep mata kuliah kuantum kelas eksperimen lebih baik dibanding kelas kontrol di setiap materinya. Perbandingan N-gain antara kedua kelas untuk setiap materi ditampilkan pada Gambar 2.

Pada Gambar 2 terlihat bahwa pada pokok bahasan teori yang mendasari lahirnya fisika kuantum pada kelas kontrol terlihat tidak terdapat peningkatan $\mathrm{N}$-gain karena kelas konvensional rendahnya motivasi berprestasi, untuk keempat pokok bahasan yang lain terlihat nilai $\mathrm{N}$-gain kelas eksperimen lebih tinggi dari kelas kontrol. Selanjutnya data-data yang diperoleh dari hasil penelitian yang berupa skor motivasi belajar dan hasil belajar siswa dianalisis dengan analisis variansi dua jalan sel tak sama dan uji Mann-Whitney. Tabel 6 memperlihatkan rangkuman pengujian analisis varian dua jalan. 


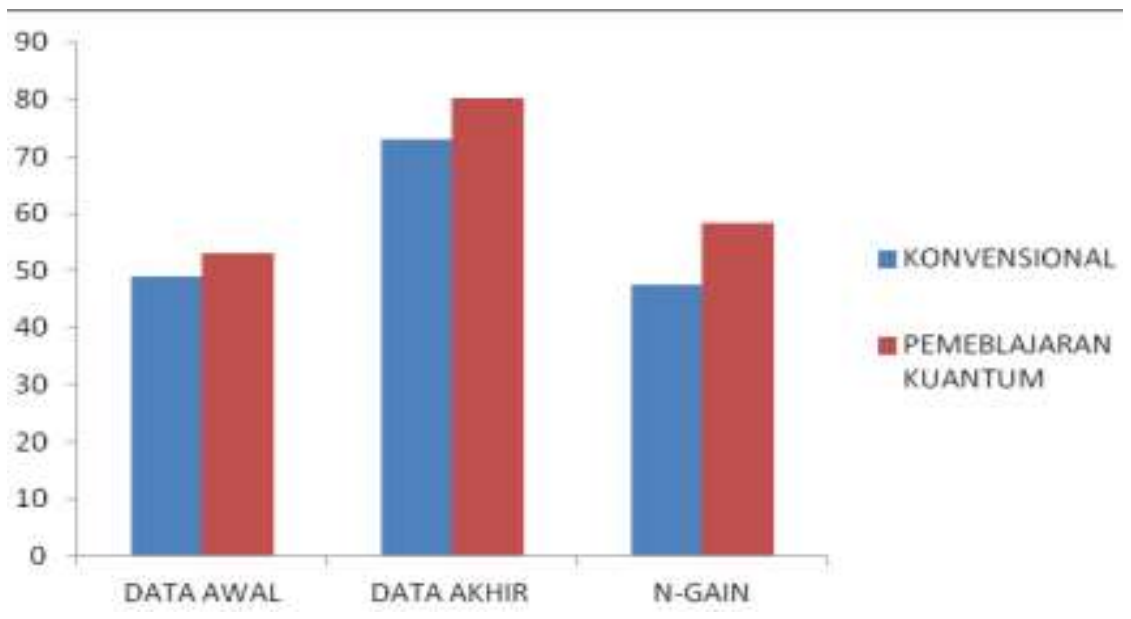

Gambar 1. Perbandingan tes awal, tes akhir, dan N-gain kelas kontrol (konvensional) dan eksperimen (pembelajaran kuantum)

Tabel 5. Data Peningkatan (N-gain) Prestasi Belajar Materi Fisika Kuantum

Keterangan :

\begin{tabular}{lcclll}
\hline Kelas & Pb1 & Pb2 & Pb3 & Pb4 & Pb5 \\
\hline Kontrol & 0,00 & 15,28 & 17,99 & 55,98 & 42,24 \\
Eksperimen & 48,33 & 55,17 & 59,04 & 60,45 & 68,95 \\
\hline
\end{tabular}

$\mathrm{Pb} 1$ = Teori yang Mendasari Lahirnya fisika Kuantum

$\mathrm{Pb} 2$ = Konsep-konsep dasar fisika kuantum

$\mathrm{Pb} 3$ = Operator dalam Fisika Kuantum

$\mathrm{Pb} 4=$ Persamaan Gerak dalam Fisika Kuantum

$\mathrm{Pb} 5=$ Potensial Sederhana

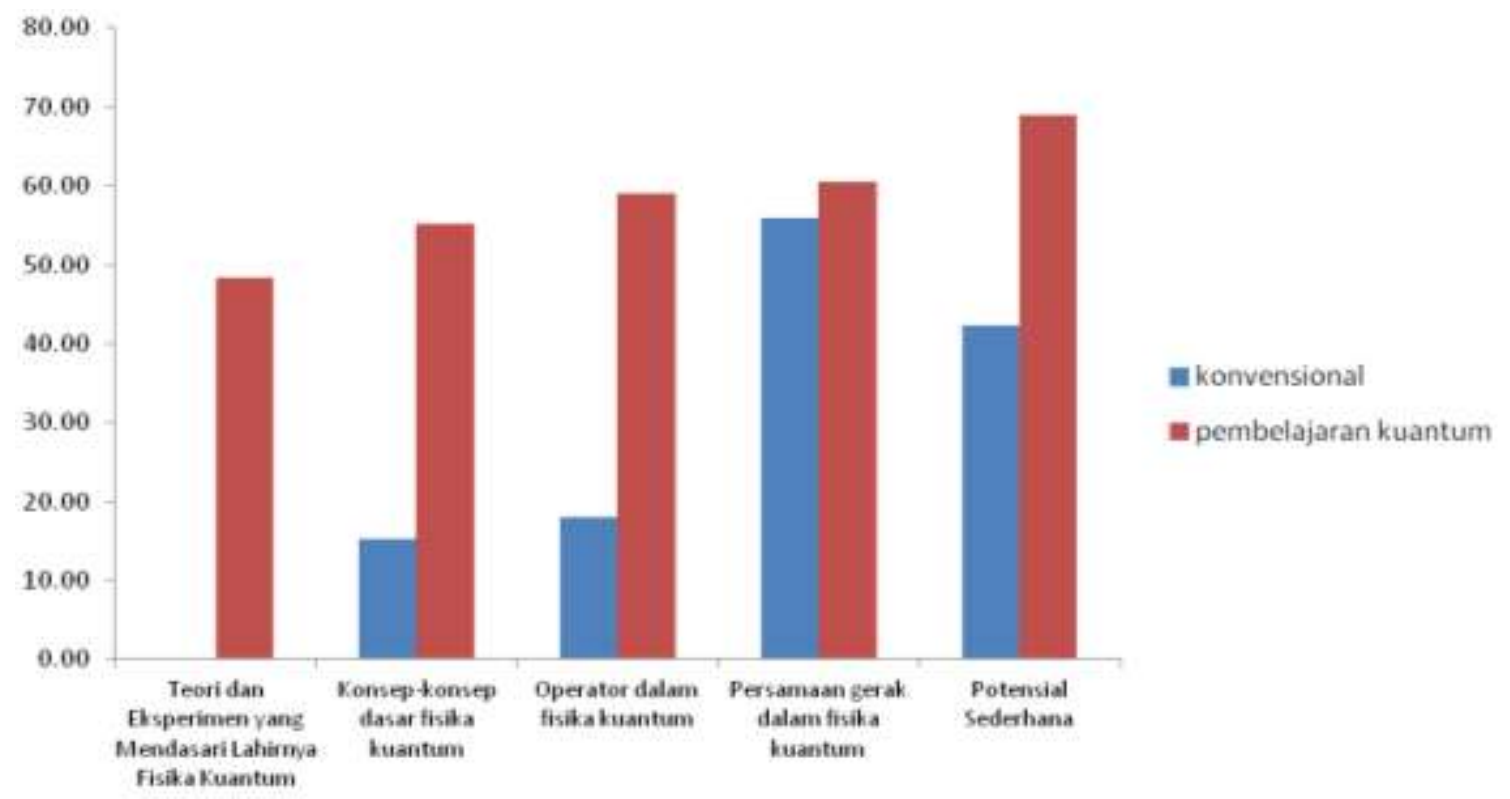

Gambar 2. N-gain kelas kontrol dan eksperimen untuk setiap materi pembelajaran

Berdasarkan tabel rangkuman analisis variansi dua jalan di atas didapatkan hasil sebagai berikut:

a. Taraf signifikansi untuk model pembelajaran konvensional dan pembelajaran kuantum, yaitu
$(0,047<0,050)$ sehingga hipotesis nol ditolak dan hipotesis alternatif diterima, maka terdapat pengaruh model pembelajaran konvensional dan kuantum terhadap prestasi belajar belajar fisika 
kuantum. Hal ini disebabkan karena pada pembelajaran kuantum terdapat prosedurprosedur yang digariskan secara jelas apa yang harus dilakukan oleh para mahasiswa dengan pola pembelajaran TANDUR sehingga ada sinergi interaksi pembelajaran yang menumbuhkan semangat belajar, mengalami sendiri secara aktif, menganalisis penurunan rumus kuantum, mendemonstrasikan kedepan kelas, mengulangi materi yang diberikan dan merayakan bersama keberhasilan dalam menguasai materi. Sedangkan pada pebelajaran konvensional, model pembelajaran yang menekankan fakta dalam kehidupan, sehingga tidak semua materi pada fisika kuantum dapat berjalan efektif karena mahasiswa sulit mengaitkan masalah-masalah yang ingin diselesaikan dengan kehidupan nyata.

Dalam proses berpikirnya, mahasiswa yang terkesan malas dan kurang bersemangat dalam belajar, hal ini terlihat dari masih adanya mahasiswa yang terlihat acuh dalam pelajaran fisika kuantum.

b. Taraf signifikansi untuk motivasi berprestasi, yaitu $(0,000<0,050)$ sehingga hipotesis nol ditolak dan hipotesis alternatif diterima, maka terdapat pengaruh motivasi berprestasi tinggi dan rendah terhadap prestasi belajar fisika kuantum. $\mathrm{Hal}$ ini terlihat bahwa prestasi belajar mahasiswa yang mempunyai motivasi berprestasi tinggi mempunyai rata-rata prestasi yang lebih besar dibanding siswa yang mempunyai motivasi berprestasi rendah. Hal ini disebabkan karena mahasiswa dalam proses belajar yang memiliki motivasi berprestasi tinggi tidak mudah menyerah dalam mengerjakan tugas, mengumpulkan tugas yang terbaik, mencari cara-cara yang unik dalam menyelesaikan masalah dan mempunyai sikap kreatif dalam belajar fisika kuantum.

c. Taraf signifikansi untuk interaksi model pembelajaran dengan motivasi berprestasi, yaitu $(0,190>0,050)$ sehingga hipotesis nol diterima. Hal ini berarti bahwa tidak terdapat interaksi antara model pembelajaran dengan motivasi berprestasi mahasiswa. Mahasiswa yang menggunakan model pembelajaran konvensional dan memiliki motivasi berprestasi tinggi prestasi belajarnya lebih baik daripada mahasiswa yang memiliki motivasi berprestasi rendah. Mahasiswa dengan motivasi berprestasi tinggi pada model pembelajaran kuantum juga memberikan prestasi belajar yang lebih baik daripada mahasiswa yang memiliki motivasi berprestasi rendah. Mahasiswa dengan motivasi berprestasi tinggi memiliki prestasi belajar yang lebih baik pada kelas yang menggunakan model pembelajaran kuantum, dimana nilai rata-rata tes akhir hasil belajarnya lebih besar dibanding dengan model pembelajaran konvensional. Sebaliknya mahasiswa dengan motivasi berprestasi rendah memiliki prestasi belajar yang paling rendah terdapat pada kelas yang menggunakan model pembelajaran konvensional. Ini membuktikan bahwa keterkaitan antara motivasi berprestasi dan model pembelajaran tidak tampak dalam prestasi belajar yang diperoleh mahasiswa.

Selanjutnya analisis data diatas dapat dilakukan analisis lanjut untuk setiap pokok bahasan berupa skor motivasi belajar dan prestasi belajar yang ditunjukkan pada Tabel 7 sampai dengan Tabel 11.

Berdasarkan Tabel 7 rangkuman analisis variansi dua jalan di atas didapatkan hasil sebagai berikut:

a. Taraf signifikansi untuk model pembelajaran, yaitu $(0,000<0,050)$ sehingga hipotesis nol ditolak dan hipotesis alternatif diterima.

b. Taraf signifikansi untuk motivasi berprestasi, yaitu $(0,006<0,050)$ sehingga hipotesis nol ditolak dan hipotesis alternatif diterima.

c. Taraf signifikansi untuk interaksi model pembelajaran dengan motivasi berprestasi yaitu $(0,160>0,050)$ sehingga hipotesis nol diterima dan hipotesis alternatif ditolak

Berdasarkan Tabel 8 rangkuman analisis variansi dua jalan di atas didapatkan hasil sebagai berikut:

a. Taraf signifikansi untuk model pembelajaran, yaitu $(0,000<0,050)$ sehingga hipotesis nol ditolak dan hipotesis alternatif diterima,

b. Taraf Signifikansi untuk motivasi berprestasi, yaitu $(0,130>0,050)$ sehingga hipotesis nol diterima dan hipotesis alternatif ditolak.

c. Taraf Signifikansi untuk interaksi model pembelajaran dengan motivasi berprestasi, yaitu $(0,483>0,050)$ sehingga hipotesis nol diterima dan hipotesis alternatif ditolak

Berdasarkan Tabel 9 rangkuman analisis variansi dua jalan di atas didapatkan hasil sebagai berikut:

a. Taraf signifikansi untuk model pembelajaran, yaitu $(0,000<0,050)$ sehingga hipotesis nol ditolak dan hipotesis alternatif diterima.

b. Taraf signifikansi untuk motivasi berprestasi, yaitu $(0,107>0,050)$ sehingga hipotesis nol diterima dan hipotesis alternatif ditolak.

c. Taraf signifikansi untuk interaksi model pembelajaran dengan motivasi berprestasi yaitu $(0,006<0,050)$ sehingga hipotesis nol ditolak dan hipotesis alternatif diterima. 
Tabel 6. Rangkuman Analisis Variansi Dua Jalan Sel Tak Sama Untuk Nilai Kemampuan Awal Dan Akhir Proses Pembelajaran Fisika Kuantum

\begin{tabular}{llllll}
\hline Source & $\begin{array}{l}\text { Type III } \\
\text { Sum of } \\
\text { Squares }\end{array}$ & df & $\begin{array}{l}\text { Mean } \\
\text { Square }\end{array}$ & F & Sig. \\
\hline Corrected Model & 2529,280692 & 3 & 843,0935638 & 8,274858 & 0,000 \\
Intercept & 255016,3825 & 1 & 255016,3825 & 2502,954 & 0,000 \\
Model Pembelajaran & 429,562433 & 1 & 429,562433 & 4,216102 & 0,047 \\
Motivasi Berprestasi & 1949,677508 & 1 & 1949,677508 & 19,13584 & 0,000 \\
Interaksi Model & 181,1926593 & 1 & 181,1926593 & 1,778383 & 0,190 \\
*Motivasi Berprestasi & 4075,446581 & 40 & 101,8861645 & & \\
Error & 269332 & 44 & & & \\
Total & 6604,727273 & 43 & & & \\
Corrected Total & & & & & \\
\hline
\end{tabular}

a. R Squared $=.383$ (Adjusted R Squared $=.337$ )

Tabel 7. Rangkuman Analisis Variansi Dua Jalan Sel Tak Sama Untuk Pokok Bahasan Teori Dan Eksperimen Yang Mendasari Lahirnya Fisika Kuantum

\begin{tabular}{|c|c|c|c|c|c|}
\hline Source & $\begin{array}{l}\text { Type III Sum of } \\
\text { Squares }\end{array}$ & df & $\begin{array}{l}\text { Mean } \\
\text { Square }\end{array}$ & $\mathbf{F}$ & Sig. \\
\hline $\begin{array}{l}\text { Corrected } \\
\text { Model }\end{array}$ & $1224,812^{\mathrm{a}}$ & 3 & 408,271 & 15,812 &, 000 \\
\hline Intercept & 202205,066 & 1 & 202205,066 & 67831,147 & 7,000 \\
\hline $\begin{array}{l}\text { Model } \\
\text { Pembelajaran }\end{array}$ & 930,129 & 1 & 930,129 & 36,023 &, 000 \\
\hline $\begin{array}{l}\text { Motivasi } \\
\text { Berprestasi }\end{array}$ & 219,565 & 1 & 219,565 & 8,503 & ,006 \\
\hline $\begin{array}{l}\text { Model * } \\
\text { Motivasi }\end{array}$ & 52,477 & 1 & 52,477 & 2,032 & ,162 \\
\hline Error & 1032,825 & 40 & 25,821 & & \\
\hline Total & 212294,000 & 44 & & & \\
\hline Corrected Total & 2257,636 & 43 & & & \\
\hline
\end{tabular}

Tabel 8. Rangkuman Analisis Variansi Dua Jalan Sel Tak Sama Untuk Pokok Bahasan Konsep-Konsep Dasar Fisika Kuantum

\begin{tabular}{|c|c|c|c|c|c|}
\hline Source & $\begin{array}{l}\text { Type III Sum } \\
\text { of Squares }\end{array}$ & df & $\begin{array}{l}\text { Mean } \\
\text { Square }\end{array}$ & $\mathbf{F}$ & Sig. \\
\hline$\overline{\text { Corrected Model }}$ & $1221,881^{\mathrm{a}}$ & 3 & 407,294 & 22,176 & ,000 \\
\hline Intercept & 224186,748 & 1 & 224186,748 & 12206,211 & 1,000 \\
\hline $\begin{array}{l}\text { Model } \\
\text { Pembelajaran }\end{array}$ & 1148,439 & 1 & 1148,439 & 62,529 &, 000 \\
\hline $\begin{array}{l}\text { Motivasi } \\
\text { Berprestasi }\end{array}$ & 43,963 & 1 & 43,963 & 2,394 &, 130 \\
\hline Model * Motivasi & i 9,199 & 1 & 9,199 &, 501 & ,483 \\
\hline Error & 734,665 & 40 & 18,367 & & \\
\hline Total & 235266,000 & 44 & & & \\
\hline Corrected Total & 1956,545 & 43 & & & \\
\hline
\end{tabular}


Tabel 9. Rangkuman Analisis Variansi Dua Jalan Sel Tak Sama Untuk Pokok Bahasan Operator Dalam Fisika Kuantum

\begin{tabular}{lllllr}
\hline Source & $\begin{array}{l}\text { Type III } \\
\text { Sum of } \\
\text { Squares }\end{array}$ & df & $\begin{array}{l}\text { Mean } \\
\text { Square }\end{array}$ & F & Sig. \\
\hline Corrected Model & $460,951^{\text {a }}$ & 3 & 153,650 & 27,288 &, 000 \\
Intercept & 250632,804 & 1 & 250632,804 & $44511,206,000$ \\
Model Pembelajaran & 394,719 & 1 & 394,719 & 70,100 &, 000 \\
Motivasi Berprestasi & 15,318 & 1 & 15,318 & 2,720 &, 107 \\
Model * Motivasi & 47,336 & 1 & 47,336 & 8,407 &, 006 \\
Error & 225,231 & 40 & 5,631 & & \\
Total & 259104,000 & 44 & & & \\
Corrected Total & 686,182 & 43 & & \\
\hline
\end{tabular}

Tabel 10. Rangkuman Analisis Variansi Dua Jalan Sel Tak Sama Untuk Pokok Bahasan Potensial Sederhana

\begin{tabular}{llllll}
\hline Source & $\begin{array}{l}\text { Type III Sum of } \\
\text { Squares }\end{array}$ & df & $\begin{array}{l}\text { Mean } \\
\text { Square }\end{array}$ & F & Sig. \\
\hline $\begin{array}{l}\text { Corrected } \\
\text { Model }\end{array}$ & $1827,432^{\mathrm{a}}$ & 3 & 609,144 & 158,500 &, 000 \\
Intercept & 267586,305 & 1 & $\begin{array}{l}267586,30 \\
6\end{array}$ & 69626,400 &, 000 \\
$\begin{array}{l}\text { Model } \\
\begin{array}{l}\text { Pembelajaran } \\
\text { Motivasi }\end{array}\end{array}$ & 1825,149 & 1 & 1825,149 & 474,907 &, 000 \\
$\begin{array}{l}\text { Berprestasi } \\
\text { Model } *\end{array}$ &, 583 & 1 &, 583 &, 152 &, 699 \\
$\begin{array}{l}\text { Motivasi } \\
\text { Error }\end{array}$ & 1,453 & 1 & 1,453 &, 378 &, 542 \\
$\begin{array}{l}\text { Total } \\
\text { Corrected Total 1981,159 }\end{array}$ & 153,727 & 40 & 3,843 & & \\
\hline R Squared =,922 (Adjusted R Squared $=, 917)$ & & \\
\hline
\end{tabular}

Berdasarkan Tabel 10 rangkuman analisis variansi dua jalan di atas didapatkan hasil sebagai berikut:

a. Taraf signifikansi untuk model pembelajaran, yaitu $(0,000<0,050)$ sehingga hipotesis nol ditolak dan hipotesis alternatif diterima.

b. Taraf signifikansi untuk motivasi berprestasi, yaitu $(0,699>0,050)$ sehingga hipotesis nol diterima dan hipotesis alternatif ditolak.

c. Taraf signifikansi untuk interaksi model pembelajaran dengan motivasi berprestasi yaitu $(0,542>0,050)$ sehingga hipotesis nol diterima dan hipotesis alternatif ditolak.

Tabel 11. Rangkuman Analisis Variansi Dua Jalan Sel Tak Sama Untuk Pokok Bahasan Persamaan Gerak dalam Fisika kuantum

\begin{tabular}{ll}
\hline Statistik & Nilai \\
\hline Mann-Whitney U & 0,000 \\
Wilcoxon W & 190,000 \\
Z & $-5,663$ \\
Asymp. Sig. (2-tailed) & 0,000 \\
\hline
\end{tabular}

Berdasarkan tabel rangkuman Uji Mann-Whitney di atas didapatkan hasil sebagai berikut: Taraf signifikansi untuk model pembelajaran yaitu $(0,000<$ $0,050)$ sehingga hipotesis nol ditolak dan hipotesis alternatif diterima

\section{Penutur}

Berdasarkan keseluruhan data yang dikumpulkan dan hasil dari analisis data untuk setiap pokok bahasan yang diperoleh dapat disimpulkan beberapa hal, yaitu: Ada pengaruh model pembelajaran konvensional dan kuantum terhadap prestasi belajar fisika kuantum mahasiswa program studi pendidikan fisika Universitas Mataram. Mahasiswa yang diajar menggunakan model pembelajaran kuantum memberikan prestasi belajar yang lebih tinggi dibanding dengan mahasiswa yang diajar menggunakan model pembelajaran konvensional.

Ada pengaruh motivasi berprestasi yang terhadap prestasi belajar fisika kuantum mahasiswa program studi pendidikan fisika Universitas Mataram. Mahasiswa yang memiliki motivasi berprestasi tinggi akan memberikan hasil belajar yang lebih tinggi 
dibanding dengan mahasiswa yang memiliki motivasi berprestasi rendah.

Tidak ada interaksi antara model pembelajaran dengan motivasi berprestasi terhadap hasil belajar fisika kuantum mahasiswa.

\section{UCAPAN TERIMA KASIH}

Terima kasih penulis ucapkan pada seluruh mahasiswa pendidikan fisika tahun pelajaran 2011/2012 dan ucapan terima kasih pada bapak Drs Asrul, MA., (UNP), bapak Prof. Muslim, Ph.D (alm) (UGM) dan Prof. Elias Saion, Ph.D (UPM) yang telah memberikan ilmu fisika kuantum sewaktu perkuliahan, dan semua pihak yang telah membantu sehingga terselesainya artikel ini sehingga bermanfaat untuk pembaca.

\section{REFERENSI}

[1] Kurikulum 2013, Peraturan Menteri Pendidikan Dan Kebudayaan Republik Indonesia Nomor 49 Tahun 2014.

[2] Sardiman, A., Interaksi dan Motivasi Belajar Mengajar, Jakarta PT Raja 2006.

[3] Suyatno, Pembelajaran Kuantum , Jakarta Rineka, 2009.

[4] Aqib, Zainal, Profesionalisme Guru Dalam Pembelajaran, Insan Cendekia, 2010.
[5] De Porter, Bobbi., Mike Hernacki., Quantum Learning Membiasakan Belajar Nyaman dan Menyenangkan. Bandung: Kaifa, 2010.

[6] Petri, Motivasi Berprestasi, Bandung, Remaja Rosda Karya, 2001.

[7] Beck, W., The Teaching of Science, Jakarta Bumi Aksara, 1992.

[8] Suyatno, Menjelajah Pembelajaran Inovatif, Sidoarjo: Masmedia Buana Pustaka. 2009.

[9] Sugiono, Metode Penelitian Pendidikan. Bandung : Alfabeta. 2013.

[10] Doyan, Aris., Buku Ajar Fisika Kuantum, Universitas mataram Press, 2014.

[11] Chenk, K., Using Online Homeworks System Enhances Student Learning of Physics Concept in an Introductory Physics Course. American Journal of Physics. 72 (11) 1447-1453., 2004.

\section{Biografi Penulis}

Aris Doyan, lahir di Sumatera Barat 15 Nopember 1967 menyelesaikan program sarjana pendidikan fisika di Universitas Negeri Padang 1992, menyelesaikan program Magister ilmu fisika di Universitas Gadjah Mada 1998, menyelesaikan program doktor falsafah di University Putra Malaysia 2005. 